\title{
Most common injuries of the musculoskeletal system among children of elementary school age who engage in gymnastic sports (aerobics, artistic or rhythmic gymnastics) at an elite level
}

\author{
Kristina Hassmannová*, Dagmar Pavlů, Tereza Nováková
}

Department of Physiotherapy, Faculty of Physical Education and Sport, Charles University, Prague, Czech Republic

* Corresponding author: hassmannova.kristina@gmail.com

This study was developed within the Charles University PROGRESS Programme Q41.

\begin{abstract}
Background. The main objective was to find out which musculoskeletal system problems (pain and/or injuries) are the most common among girls of elementary school age who engage in gymnastic sports at an elite level. We were also interested in the influence of the success of girls in gymnastics competitions on problems of the musculoskeletal system. In connection with the pain and injuries of the musculoskeletal system, we asked whether the gymnasts were monitored professionally on the medical side, whether they regularly engaged in primary or secondary physiotherapeutic care.

Methods. The data were obtained by combining qualitative and quantitative research in the form of a structured interview and a questionnaire. Retrospective data were collected. The research group consisted of 58 girls (average age 13.5 years) engaging in gymnastic sports at an elite level.

Results. A musculoskeletal system problem occurred in $98 \%$ female gymnasts during their elementary school age. Their lower limbs, specifically the knees and ankles, appeared to be the most susceptible parts of the musculoskeletal system. Multiple musculoskeletal system problems were more frequent than single isolated problems. As far as the correlation between the incidence of pain/injury and the girls' individual performance level is concerned, gymnasts assuming non-medal positions had a higher incidence of pain and injuries than the medal-winning gymnasts. The higher incidence of injuries in non-medal gymnasts compared to medal gymnasts was confirmed by statistical analysis. Physiotherapeutic prevention, whether primary or secondary, was given a minimum number of gymnasts.
\end{abstract}

(C) 2019 The Authors. This is an open-access article distributed under the terms of the Creative Commons Attribution License (http://creativecommons.org/licenses/by/4.0), which permits unrestricted use, distribution, and reproduction in any medium, provided the original author and source are credited. 
Conclusion. The results of this study demonstrate a high susceptibility to painful conditions and injuries especially of lower limbs of elite level gymnasts at their younger school age. It also proved statistically significant that gymnasts who are worse off with performance always have a higher incidence of problems with the musculoskeletal system. These results are also probably due to the fact that most of the interviewed gymnasts are not in physiotherapy or other professional care.

\section{KEYWORDS}

gymnastic sports; musculoskeletal system; pain and injuries; hyper mobility

DOI

10.14712/23366052.2019.2 


\section{INTRODUCTION}

Gymnastic sports, presumably due to their difficulty, are specific in that a large number of injuries already occur in childhood. The hazard of injury in gymnastic sports is very high because of the high demands put on the gymnast's performance, both on movement and on the intensity of training. Another risk factor is also the start of a very intense early age (Bradshaw, 2010; Lowry et al., 1982).

The children start their sports career at an age of 3-4 in preparatory courses taking place once or twice a week. The number of training units is increased step by step to reach 6-9 units a week (which can amount to more than 20 hours weekly) at the children's younger school age (Kolar, 2017).

Functional overloading of the musculoskeletal system due to a burden that is inadequately high with respect to the children's age and to a training intensity that is too high for the children to be able to cope with constitutes the highest health risk in children sporting at a competition level (Kučera et al., 2011).

In childhood, we often encounter problems with the musculoskeletal system in the form of microtraumas, manifest as pain or minor injuries, which are often not even given sufficient importance. Micro-traumas, which may have fatal consequences for the child's sports career, must be taken into account in children (Keller, 2009). Chronic damage suffered by the children during their growth does not attract much interest either because, owing to the children's high adaptive and regenerative capacity, the consequences of the inadequately high load and insufficient regeneration are not immediately apparent, but they create preconditions for musculoskeletal system problems at a higher age (Karantanas, 2010).

This study is based on an already published study (Hassmannová et al., 2018) where we focused on the deficiencies in physiotherapeutic care in connection with musculoskeletal problems in younger school age girls who are engaged in elite gymnastics sports. In this article, we will focus on the most common musculoskeletal problems of these gymnasts and their possible causes.

\section{OBJECTIVES AND METHODS}

The aim of this work was to map musculoskeletal system problems - painful conditions and injuries - in younger school age girls practising gymnastic sports at an elite level. Furthermore, we wanted to identify those parts of the musculoskeletal system that are most prone to causing pain and to injuries and find whether - and if so, then to what extent - pain or injury affect the gymnast's performance, and also how this issue is addressed from the physiotherapeutic aspect.

The research group comprised girls from Prague sports clubs of artistic and rhythmic gymnastics and gymnastic aerobic who have been practicing their sports at an elite level. Specifically, the group included 58 girls from 10 artistic gymnastics clubs, 22 girls from rhythmic gymnastics clubs and 26 girls from gymnastic aerobic clubs. The mean study subject age was $x_{\text {mean }}=13.52 \pm 1.24$ years. The following criteria, in addition to availability, were applied to the selection of the participants: girl at a younger school age, i.e. not younger than 12 years and not older than 15 years, prac- 
tising a gymnastic sport since her age of 3-4 years (in a preparatory course) and now, at her younger school age, at a high competition level.

The research combined the qualitative and quantitative approaches by using a controlled structured interview and a questionnaire. The structured interview was made with children towards or after the end of their younger school age and one of their parents was present. The data collection concept was retrospective, information from the younger school age period was recorded. The interview structure was set by a fixed questionnaire which was filled in step by step by the researcher during the interview.

Data were collected during December 2017 and January 2018. As mentioned above, one of the parents as a legal representative was present during the interview and the information gained was recorded in the questionnaire. Before starting the interview, the researcher made the study subject and her parent familiar with the interviewing procedure and information processing method, and both of them expressed their consent by signing copies of the informed consent form approved by the Ethics Committee of the Faculty of Physical Education and Sport, Charles University (Hassmannová, 2018).

Data analysis was based on the following questionnaire items:

- Training intensity (categories: $\leq 5$ hours per week, 5-10 hours per week, $>10$ hours per week).

- Sport achievements ("Medal position" means that the child often participated in competitions and won a medal in one-half of them or more).

- Other motion activities in addition to the gymnastics trainings ("Yes" means that the girl practises some motion activity other than gymnastic training at least once a week during her younger school age).

- Sports training-related pain and/or musculoskeletal system injuries (pain was defined as such musculoskeletal system pain as the child perceives regularly, is located in a defined body area and limits the child during training but does not preclude the child's participation in it; musculoskeletal system injury was defined as a condition due to which the child was unable to practise sports activity).

- Approach to the child's musculoskeletal system problems ("Professional attention" means that the girl visited a doctor or physiotherapist immediately after the problem appeared; "Prevention" means primary physiotherapeutic prevention where the child attended physiotherapeutic sessions periodically even though they had no acute problem; and "follow-up prevention" means secondary physiotherapeutic prevention where the child attended physiotherapeutic sessions periodically because of an existing or past problem).

The data were processed in the Microsoft Excel spreadsheet application. The double sample t-test method was used for statistical data processing.

\section{RESULTS}

One or more sport training-related musculoskeletal system problems of any type occurred in 57 (98\%) gymnasts at their younger school age. In other words, only one girl in the research group reported no pain or injury in relation to her sporting activity. 
The prevailing problems concerned the girls' lower limbs, back and upper limbs. The frequency of lower limb problems was up to $140 \%$ (a figure over $100 \%$ means that some girls perceived more than one problem of that type) (Graph 1).

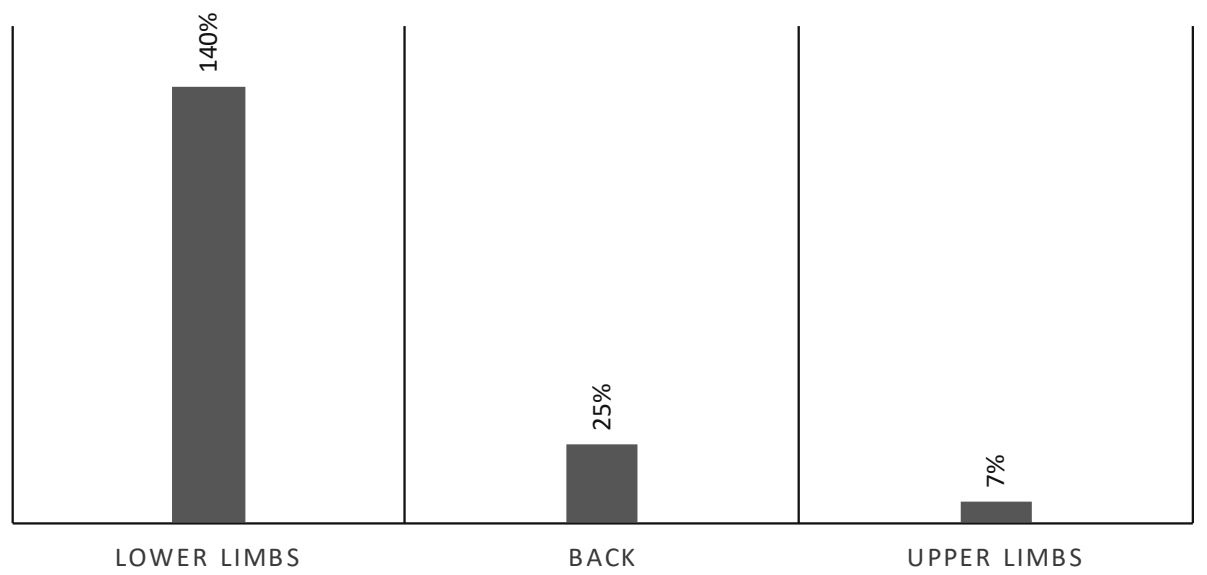

Graph 1 Problematic areas of musculoskeletal system of gymnasts of young school age

Most prone to injury in this respect were the ankles and knees. In the subgroup of girls with lower limb problems, ankle problems were reported by $40 \%$ girls, problems with knees, by $36 \%$ girls. Back pain or injury was reported by $25 \%$ girls whereas upper limb problems were reported by mere $7 \%$ girls. The following graph shows the percentage of problems on different parts of the lower limb (Graph 2).

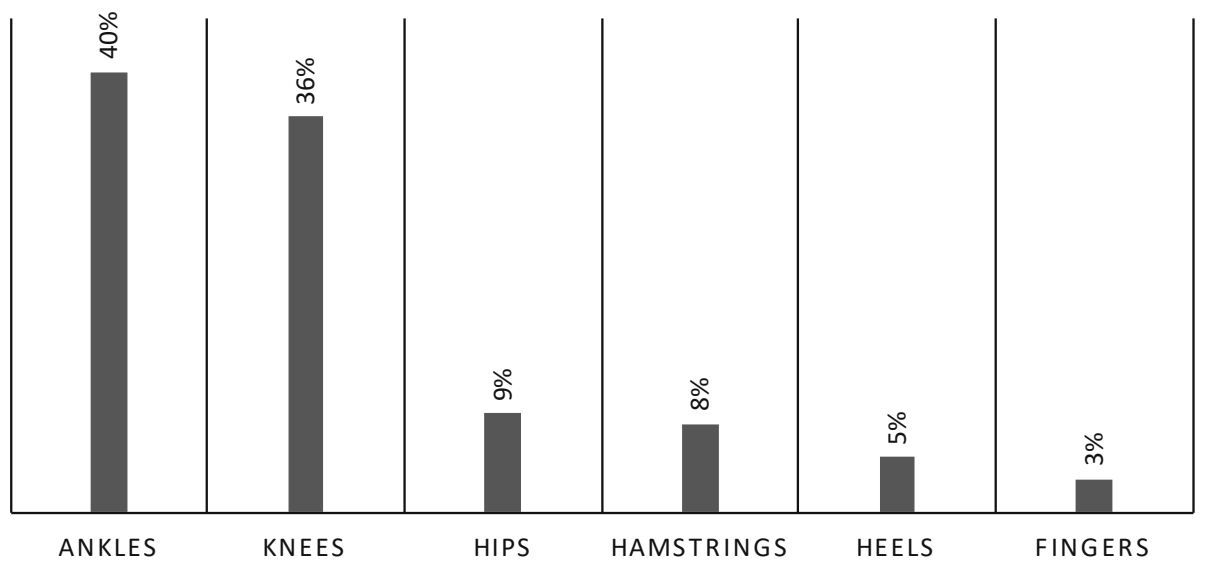

Graph 2 Pain and injuries of lower limbs in young school age gymnasts

Musculoskeletal system pain was reported more frequently than musculoskeletal system injuries. Specifically, musculoskeletal system pain was reported by $86 \%$ gymnasts at their younger school age, which is an alarming figure. Musculoskeletal system injury was reported by $48 \%$ girls, combination of pain and injury was reported by $34 \%$ girls (Graph 3). 


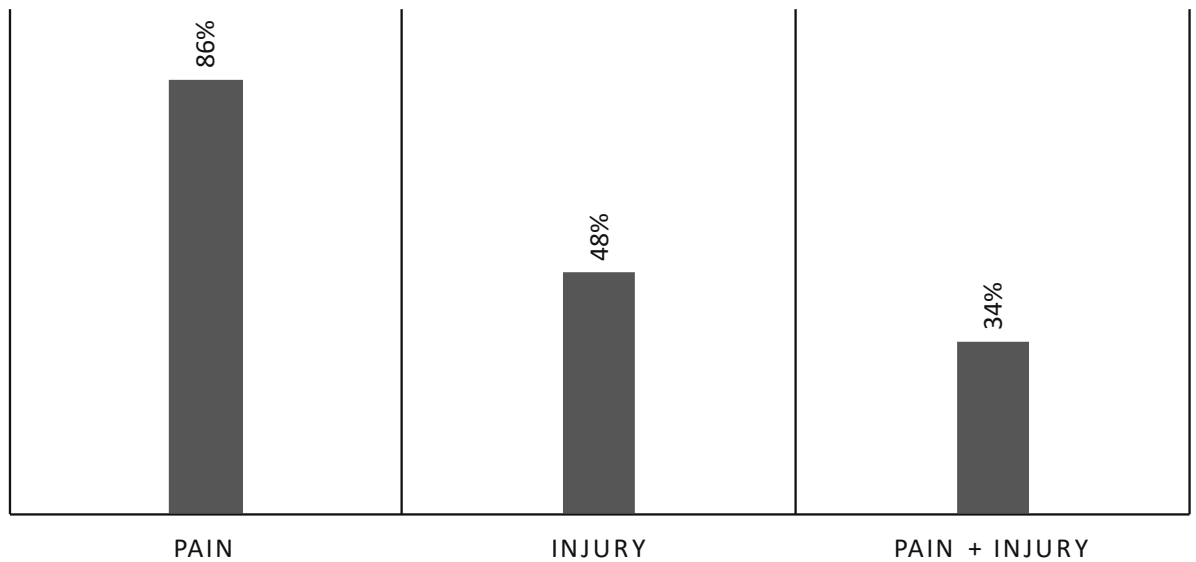

Graph 3 The occurrence of pain and injuries of the musculoskeletal system in younger school age gymnasts

\section{Relations between musculoskeletal system pain and training load/sports achievements}

As to the pain-training load relationship, the incidence of musculoskeletal system pain was paradoxically higher in gymnasts who had a lower training load. And as to the pain-sports achievements relationship, pain was reported more by gymnasts who normally attained non-medal positions than by girls who frequently won a medal at competitions (Graph 4).

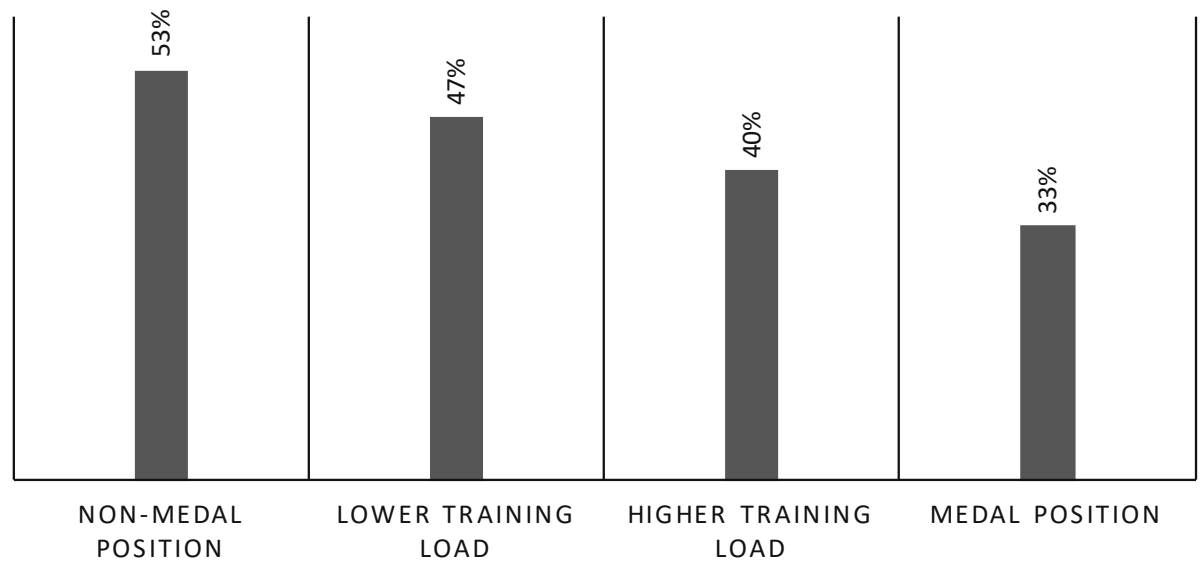

Graph 4 Pain of the musculoskeletal system in younger school age gymnasts

\section{Relations between musculoskeletal system injuries and the training load/sports achievements}

The occurrence of musculoskeletal system injuries was uniform with respect to the training load intensity. The injury-sports achievements relationship was similar to the pain-sports achievements relationship: injuries were reported more by gymnasts who normally attained non-medal positions than by girls who frequently won a medal at competitions (Graph 5). 
Statistical processing gave evidence that this fact is statistically significant, $\mathrm{p}=0.049$ (i.e., $\mathrm{p}<0.05$ ).

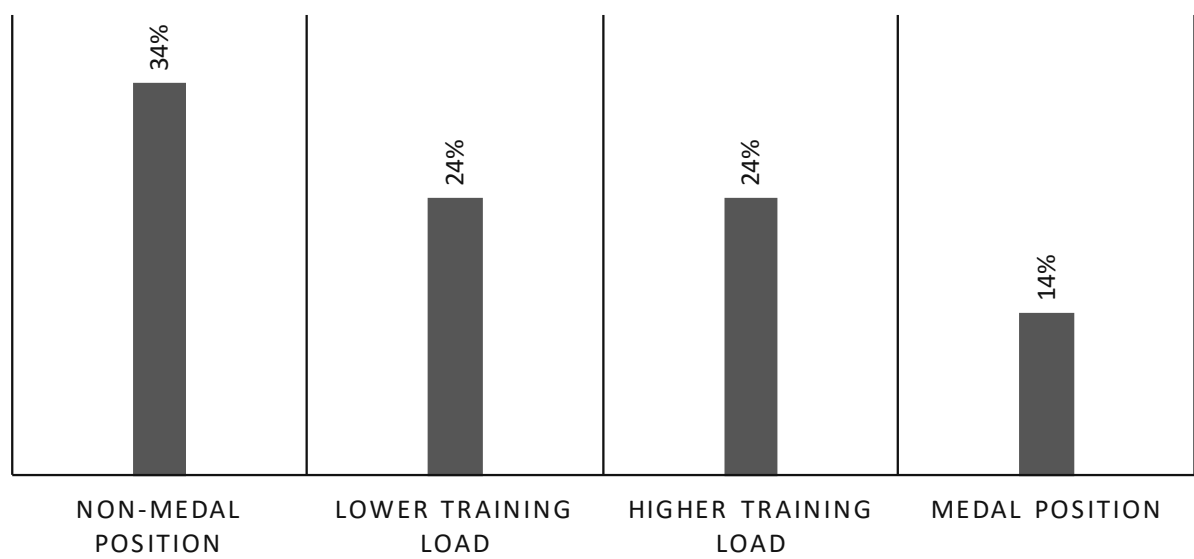

Graph 5 Injuries of the musculoskeletal system in younger school age gymnasts

\section{Professional treatment of musculoskeletal system problems}

The research results demonstrate that fewer than $29 \%$ gymnasts who experienced a musculoskeletal system problem saw a doctor or physiotherapist immediately after the problem appeared. Mere 4\% gymnasts followed a physiotherapeutic prevention program. Physiotherapeutic prevention because of a present or past musculoskeletal system problem was practised by fewer than $18 \%$ gymnasts (Graph 6).

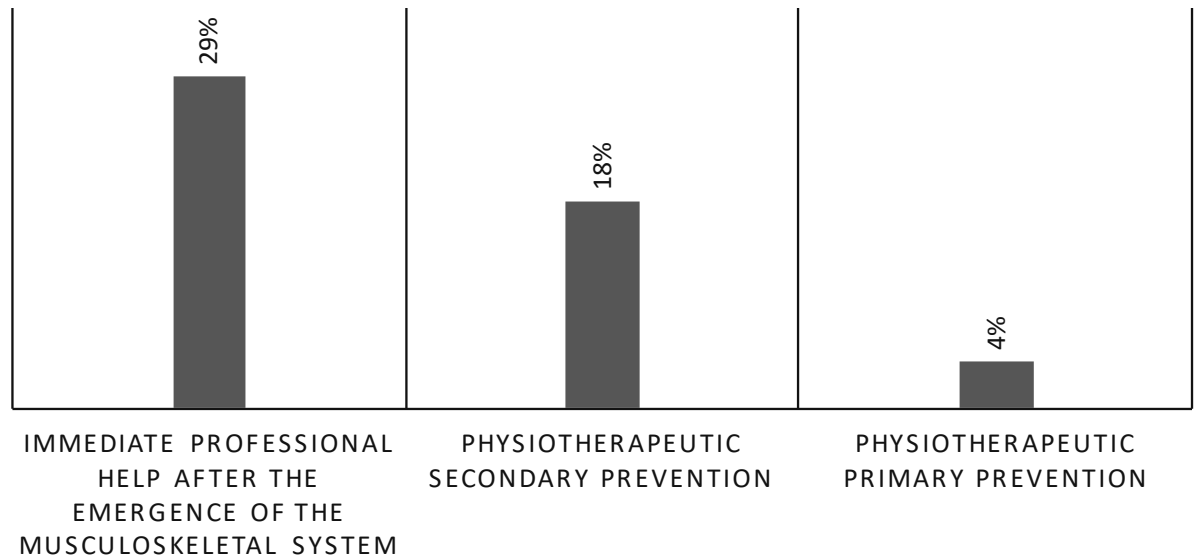

Graph 6 Professional solutions and prevention of problems of musculoskeletal system in young school age gymnasts 


\section{DISCUSSION}

The high injury rates in elite gymnasts are ascribed to the high training intensity, to the high demands for performance and also to external effects (effects of the environment, family, trainers, medical care level). Caine et al. (1989) have studied a group of elite gymnasts (female \& male) during a one-year period. One research group consisting of 50 female gymnasts reported 147 injuries, which is a $294 \%$ rate. The other group examined consisted of 31 female gymnasts and the number of injuries was 48 , i.e. $155 \%$, which agrees with the results of our study. Lowry and Leveau (1982) examined a group of 370 elite female gymnasts and recorded 260 musculoskeletal system injuries, which implies a 70\% injury rate. Other 2 studies made during the same period of time did not support a high injury risk rate of gymnastics: Goodway et al. (4) examined a group of 725 gymnasts (male \& female) and recorded 93 injuries (13\% injury rate), and Pettrone and Ricciardelli (1897) examined a group of 542 gymnasts (male \& female) and recorded 62 injuries, which provides an injury rate of mere 5\%. Presumably, the high differences between the data are due to different injury assessment methodologies applied. The studies indicate that the higher the gymnast's performance, the higher the injury risk (Lowry et al., 1982). Most prone to injury in gymnasts are their lower limbs, depending on the nature of the performance expected of the gymnast (Kirialanis et al., 2003). This is confirmed by the results of our study. In comparison of the occurrence of pain and injuries, there was a much greater occurrence of musculoskeletal system pains, which represents tiny microtrauma and functional problems of the musculoskeletal system.This result is consistent with that of Keller (2009), which describes the occurrence of microtraumas in young gymnasts. These microraumas, due to functional disorders of the musculoskeletal system, are the basis for more serious injuries in later life and endangering the entire sports career. The most common functional disorders of the musculoskeletal system are muscle imbalance arising from the specifics of gymnastic sports. Muscle imbalances disrupts the balance between agonists and antagonists and disrupts the smooth coordinated movement. Movement becomes physiologically ineffective, affects muscular and joint apparatus, and is only a matter of time before serious structural changes occur (Kolár, 1988).

Frequent injuries to lower limbs in gymnasts can explain typical muscle imbalances for gymnastics described by Kolár (1988). Muscles that bind to the lower limbs and have a tendency to weaken in gymnastics are $\mathrm{m}$. gluteus maximus and $\mathrm{m}$. vastus medialis. Weakening of the large qluteal muscle causes overloading of the hamstrings and paravertebral muscles in the lumbar region. It causes a loose and internally rotating position in the hip joint and a valgus position of the knee and ankle joint (Liebenson, 2007).

Muscles that bind to the lower limbs and have a tendency to shorten in gymnastics are $\mathrm{m}$. iliopsoas, tensor fasciae latae, $\mathrm{m}$. rectus femoris. Shortening of $\mathrm{m}$. iliopsoas causes lower cross syndrome. The shortening of tensor fasciae latae causes the proximal end of the tibia, the valgus of the knee joint, and the weakness of the $\mathrm{m}$. vastus medialis, which weakness the stability of the knee joint. Shortening of tensor fascia latae is one of the causes of functional disorders of the knee joint (Kolár, 1988; Liebenson, 2007). 
Given the results regarding the professional treatment of musculoskeletal system problems, we also attribute the frequent occurrence of problems with musculoskeletal system to gymnasts with minimal professional health care, as rehabilitation medicine or physical therapy. Frequent occurrences of problems in the lower limbs may have a negative impact on the entire musculoskeletal system without additional physioterapical intervention and cause further injury. The incidence of injuries to more parts of the musculoskeletal system is already beginning to appear at a young age, as shown by the results of our study. We assume that with increasing age of gymnasts and increasing training intensity the problems of the musculoskeletal apparatus will be even worse. Physiotherapeutic prevention can prevent the development of functional problems of the musculoskeletal system described above and thus reduce the risk of injury in gymnastic sports overall.

Surprisingly, when studying our group of high training intensity gymnasts, we recorded a higher incidence of musculoskeletal system pain and injuries in gymnasts exposed to a lower training intensity and attaining poorer results in competitions than in gymnasts who had a higher training intensity and attained better achievements. We conclude that gymnasts in non-medal positions will always exhibit a higher injury rate than gymnasts winning medal positions. What remains to be clarified is whether this inverse relation between the injury rate and the gymnast's ability to attain a medal position is associated with some innate disposition and motion formulas, whether innate or acquired by optimal training. We conclude that even though their training is equally intensive and proceeds under the same leadership, the gymnasts assuming non-medal positions are unable to attain the same level of performance as their more successful colleagues and their risk of injury is higher. All this shows that some individuals are successful, are able cope with high training loads and have good achievements whereas other individuals are not that successful, have more musculoskeletal system problems and the suitability this type of sport for them is questionable. Hence, the selection of a suitable sport for a child is an issue of crucial importance.

Hypermobility is a major risk factor in the gymnast's proneness to musculoskeletal system pain and injury. Hypermobility (acquired or congenital) is found in nearly all female gymnasts. Enhanced connective tissue and ligament laxicity results in repeated motions exceeding the physiological barrier, which are actually supported by the gymnastic sports, whereby the risk of premature occurrence of degenerative changes is enhanced. Individuals with diagnosed constitutional hypermobility are more prone to the development of a defective body posture and the associated musculoskeletal system problems, which are amplified by sports training (Grabara, 2010; Satrapová \& Nováková, 2012).

The child's immature brain is unable to rationally assess the consequences of starting fatigue and lower achievements, whereupon the risk of injury increases, and it is the trainer's or parent's responsibility to watch the child's fatigue, maintain it in tolerable limits and prevent its transition into pathology (Balyi \& Stafford, 2005). It is a false belief that the child's body is more resistant to fatigue. In fact, children are only unable to perceive their body so well as adults. We feel that children are less prone to tiredness because the child's body tone is shifted more to the stimulated sympathetic nervous system, with a relatively attenuated parasympathetic system also during a relative rest (Kučera et al., 2011). 


\section{CONCLUSION}

The study showed a high incidence of musculoskeletal problems among younger school-age girls engaged in gymnastics at an elite level. The most susceptible are the lower limbs, namely the ankle and knee joints. Problems of the musculoskeletal system are also frequently encountered, the most frequent being the ankle and knee joints.

There are several reasons for the frequent occurrence of pain and injury at such a low age. The main reasons are the high level of sport, the high training intensity and the absence of professional, physiotherapeutic care for gymnasts from childhood. Insufficient physiotherapeutic care compared to the incidence of musculoskeletal problems was confirmed in our study.

Injury prevention in gymnastic sports requires an interdisciplinary and multi-sided approach of all professionals and the child's family who wish to responsibly contribute to the preparation of gymnasts from the very beginning as far as the elite level.

\section{REFERENCES}

Balyi, I., \& Stafford, I. (2005). Coaching for Long-Term Athlete Development. Leeds: Coachwise UK.

Bradshaw, E. J. (2010). Performance and health concepts in artistic gymnastics. International Symposium on Biomechanics in Sports: Conference Proceedings Archive, 28, 51-55.

Caine, O. J., et al. (1989). An epidemiologic investigation of injuries affecting young competitive female gymnasts. American Journal of Sports Medicine, 17(6), 811-820.

Goodway, J., et al. (1989). The distribution of injuries among young female gymnasts in relation to selected training and environmental factors. Abstract. Paediatric Work Physiology, Symposium, Leuven.

Grabara, M. (2010). Postural variables in girls practicing sport gymnastics. Biomedical Human Kinetics, 2, 74-77.

Hassmannová, K. (2018). Nejčastějši zranění pohybového aparátu u dětí mladšiho školního věku, které se věnuji vrcholově gymnastickému aerobiku, sportovní nebo moderní gymnastice. Master's thesis. Prague: UK FTVS.

Hassmannová, K., Nováková, T., Satrapová, L., \& Pavlů, D. (2018). Nedostatky ve fyzioterapeutické péči v souvislosti se zraněními pohybového aparátu u dětí školního věku, které se věnují vrcholově gymnastickým sportům (gymnastickému aerobiku, sportovní nebo moderní gymnastice). Rehabilitace a fyzikální lékařství, 25(4), 165-170.

Karantanas, A. H. (2010). Sports injuries in children and adolescents. New York: Springer.

Keller, M. S. (2009). Gymnastics injuries and imaging in children. Pediatric Radiology, 39(12), 1299.

Kirialanis, P., Malliou, P., Beneka, A., Giannakopoulos, K. (2003). Occurrence of acute lower limb injuries in artistic gymnasts in relation to event and exercise phase. British Journal of Sports Medicine, 37(2), 137-139.

Kolar, E., Pavletič, M. S., Smrdu, M., \& Atikovič, A. (2017). Athletes' perception of the causes of injury in gymnastics. The Journal of Sports Medicine and Physical Fitness, 57(5), 703-710.

Kolář, P. (1988). Fyziologie hybnosti, relaxace a kompenzační cvičení ve sportovni gymnastice. Prague: ČO ČSTV.

Kučera, M., Kolář, P., \& Dylevský, I. (2011). Ditě, sport a zdraví. Prague: Galén.

Liebenson, C. (2007). Rehabilitation of the spine: a practitioner's manual. 2nd ed. Philadelphia: Lippincott Williams. 
Lowry, C. B., \& Leveau, B. F. (1982). A retrospective study of gymnastic injuries to competitors and noncompetitors in private clubs. American Journal of Sports Medicine, 10(4), 237-239.

Meeusen, R., \& Borms, J. (1992). Gymnastic Injuries. Sports Medicine, 13(5), 337-356.

Pettrone, F. A., \& Ricciardelli, E. (1987). Gymnastic injuries: the Virginia experience 1982-1983. American Journal of Sports Medicine, 15(1), 59-62.

Sands, W. A. (2000). Injury Prevention in Women's Gymnastics. Sports Medicine, 30(5), 359-373.

Satrapová, L., \& Nováková, T. (2012). Hypermobilita ve sportu. Rehabilitace a fyzikální lékařství, 19(4), 199-202.

Stošić, D., Milenković, S., \& Živković, D. (2011). The influence of sport on the devolopment of postural disorders in athletes. Facta Universitatis, 9(4), 375-384. 